\title{
Motor Device
}

National Cancer Institute

\section{Source}

National Cancer Institute. Motor Device. NCI Thesaurus. Code C50077.

A device designed to convert energy into mechanical motion. 